\title{
Dialogue between estrogen receptor and E2F signaling pathways: The transcriptional coregulator RIP140 at the crossroads*
}

\author{
Marion Lapierre ${ }^{1,2,3,4}$, Aurélie Docquier ${ }^{1,2,3,4}$, Audrey Castet-Nicolas ${ }^{1,2,3,4}$, Stéphan Jalaguier ${ }^{1,2,3,4}$, \\ Catherine Teyssier ${ }^{1,2,3,4}$, Patrick Augereau ${ }^{1,2,3,4}$, Vincent Cavaillès ${ }^{1,2,3,4}$ \\ ${ }^{1}$ IRCM-Institut de Recherche en Cancérologie de Montpellier, Montpellier, France \\ ${ }^{2}$ INSERM, U896, Montpellier, France \\ ${ }^{3}$ Université Montpellier1, Montpellier, France \\ ${ }^{4}$ Institut Régional du Cancer Montpellier, Montpellier, France \\ Email: vincent.cavailles@,inserm.fr
}

Received 25 July 2013; revised 25 August 2013; accepted 19 September 2013

Copyright (C) 2013 Marion Lapierre et al. This is an open access article distributed under the Creative Commons Attribution License, which permits unrestricted use, distribution, and reproduction in any medium, provided the original work is properly cited.

\begin{abstract}
Estrogen receptors and E2F transcription factors are the key players of two nuclear signaling pathways which exert a major role in oncogenesis, particularly in the mammary gland. Different levels of dialogue between these two pathways have been deciphered and deregulation of the E2F pathway has been shown to impact the response of breast cancer cells to endocrine therapies. The present review focuses on the transcriptional coregulator RIP140/NRIP1 which is involved in several regulatory feed-back loops and inhibitory cross-talks between different nuclear signaling pathways. RIP140 regulates the transactivation potential of estrogen receptors and E2Fs and is also a direct transcriptional target of these transcription factors. Published data highlight the complex regulation of RIP140 expression at the transcriptional level and its potential role in transcription cross-talks. Indeed, a subtle regulation of RIP140 expression levels has important consequences on other transcription networks targeted by this coregulator. Another level of regulation implies titration mechanisms by which activation of a pathway leads to sequestration of the RIP140 protein and thus impinges other gene regulatory circuitries. Altogether, RIP140 occupies a place of choice in the dialogue between nuclear receptors and E2Fs, which could be highly relevant in various human pathologies such as cancer or metabolic diseases.
\end{abstract}

Keywords: RIP140; E2F Transcription Factors;

${ }^{*}$ Role of RIP140 in estrogen and E2F pathways.
Estrogen Receptors; Gene Expression; Cell Proliferation; Breast Cancer; Endocrine Therapies

\section{ESTROGEN RECEPTOR AND E2F SIGNALING PATHWAYS}

\subsection{Estrogen Signaling in Breast Cancer Cells}

Estrogens are steroid hormones that regulate growth and differentiation of a large number of target tissues such as the mammary gland, the reproductive tract and skeletal and cardiovascular systems [1]. Most of these events are mediated through two distinct intracellular receptors, $\mathrm{ER} \alpha$ and $\mathrm{ER} \beta$, which belong to the superfamily of nuclear receptors. ERs bind as homo- or heterodimers to specific DNA response elements (EREs) located within the regulatory regions of target genes. Indirect recruitment on target promoters also occurs through proteinprotein interaction with other transcription factors, such as Sp1 or AP-1. The ligand-dependent transcriptional activity of ERs is mediated by two distinct activation domains, a constitutive activation function-1 (AF-1) located within the $\mathrm{N}$-terminus of the molecule and a hormonedependent transactivation domain AF-2, associated with the ligand-binding domain. Depending on cell and promoter contexts, these two domains function independently or synergistically. Ligand binding induces a conformational change that facilitates the recruitment of a large set of coactivator proteins [2]. These transcription mediators act either by stabilizing the formation of a transcription preinitiation complex or by facilitating chromatin disruption through various enzymatic activities that target histone tails. On the other hand, ER $\alpha$ has been shown to in- 
teract specifically with corepressors such as the MTA1/ NuRD chromatin-remodeling complex or NCOR1 in the presence of partial antiestrogens such as 4-hydroxytamoxifen. Estrogens stimulate cell proliferation in normal developing breast tissues and in a large proportion of $\mathrm{ER} \alpha$-positive breast cancers. Endocrine therapies using selective estrogen receptor modulators or aromatase inhibitors have proven their efficacy in the prevention or treatment of breast cancer [3]. The role of estrogens in breast cancer cells appears more complex since in addition to its classical genomic actions, ER $\alpha$ also exerts rapid non-genomic effects, which involve interaction with different signal transduction proteins including the tyrosine kinase Src and the phosphatidylinositol 3-kinase (PI3K) [4]. In addition, the estrogen signaling pathway is finely regulated by multiple post-translational modifications which regulate its function and play important roles in physiopathology [5].

\subsection{E2F Transcription Factors}

E2Fs and their heterodimer partners, DPs, are central regulators of cell cycle progression and directly regulate the expression of a broad spectrum of genes involved in cell cycle regulation, DNA replication and repair, apoptosis, differentiation or development [6]. E2F1, discovered as a protein promoting the transition to $\mathrm{S}$ phase, was the founding member of the E2F family which comprises eight members in mammals. Among this family, some were initially presented as "activator E2Fs" (E2F1, 2 and 3) while the other members were mostly known as transcription repressors. E2F transcriptional activity was shown to be regulated by a large number of transcription coactivators or corepressors including the so-called pocket proteins which form the retinoblastoma tumor suppressor family (RB together with the related proteins p107 and p130) [7]. RB attenuates activator E2F action by recruiting transcriptional corepressors such as histone deacetylases (HDACs) to E2F-regulated promoters, thus mediating transcriptional repression of E2F-regulated genes. RB is a critical component of the cell cycle control machinery and as a consequence, its loss or inactivation is a major mechanism by which cancer cells attain a growth advantage during tumorigenesis [8].

\subsection{Cross-Talks between ER and E2F Signalings}

\subsubsection{Regulation of ER Signaling by E2Fs and Pocket Proteins}

A first dialogue between the two pathways deals with the regulation of ER and nuclear receptor coregulator expression by the E2F pathway. The ER $\alpha$ promoter contains two E2F binding sites in the proximal promoter region and it has been demonstrated that multimolecular complexes containing E2F $4 / 5$ are recruited on the ER $\alpha$ promoter in cycling MCF-7 and MDA-MB-231 breast cancer cell lines [9]. This suggests that the E2F pathway might be involved in the transcriptional repression of the ER $\alpha$ gene which occurs in up to one-third of breast cancers. Interestingly, a study on human breast cancer biopsies confirmed the overexpression of E2F5 in ER $\alpha$-negative breast cancers and its association with a worse outcome [10]. Steroid receptor coactivator 3 (SRC3/ NCOA3), a major transcriptional coactivator for estrogen receptors which is overexpressed in breast cancers, is also a transcriptional target of E2F transcription factors. In MCF-7 breast cancer cells, SRC3 expression is under the control of E2F1 (ectopic expression increases SRC3 levels whereas knockdown of E2F1 reduces SRC3 expression) [11]. The regulation operates at the transcriptional level and involves Sp1 response element in the proximal promoter region. At the transactivation level, $\mathrm{RB}$ has been shown to potentiate the enhancing effect of SRC2/NCOA2 on both ER $\alpha$ and ER $\beta$ activity [12] and an interaction between ER $\beta$ and p130 has been reported although the relevance of this interaction has not been investigated [13]. RB can also interact indirectly with $\mathrm{ER} \alpha$ through the RIZ protein [14]. Finally, other members of the E2F pathway such as Cdc25B [15] or cyclincdk complexes [16] have also been described as modulators of ER activity.

\subsubsection{Regulation of the E2F Pathway by Estrogens}

A main level of cross-talk between ER and E2F signaling pathways resides in the regulation of E2F1 expression by estrogens. This regulation has been observed at the mRNA level in several breast cancer cell types such as MCF-7, ZR75-1 or T47D cells [17]. Recently, ChIP experiments confirmed the presence of ER $\alpha$ on the E2F1 promoter [18]. The regulation was also detected at the E2F1 protein level which was significantly increased upon E2 treatment [19]. The regulation of E2F1 levels appears critical for the mitogenic effect of estrogens since silencing of E2F1 expression in MCF-7 breast cancer cells resulted in a loss of estrogen regulation of cell proliferation [19]. Whereas E2F1 mRNA levels are strongly increased by estrogens in MCF-7 cells, the expression of E2F2 and E2F6 mRNA is only weakly increased and that of E2F3-5 not affected [19]. However, another study reported the regulation of E2F1, E2F2, E2F7 and E2F8 mRNA by E2 in MCF-7 cells, all being sensitive to protein synthesis inhibition [20]. It should be noted that the induction of E2F1 by estrogens is modulated by various factors such as SCFskp2 [18], the IкB kinase (IKK $\alpha$ ) [21] or the transcription factor HES-1 [22]. Estrogens treatment also impacts the E2F signaling pathway at other levels by increasing the formation of active Cyclin D1Cdk4 complexes in MCF-7 cells and increasing the phosphorylation of $\mathrm{pRB}$ or by regulating the expression 
of other members of the pathway such as the Cdk-activating phosphatase Cdc25A [23-25]. Another point deals with the fact that nuclear receptor coregulators such as CBP [26], PCAF [27], ASC-2/ NCOA6 [28] or AIB1/ $\mathrm{NCOA} 3$ [29] interact with $\mathrm{E} 2 \mathrm{~F}$ and modulate its transcriptional activity. The specific role of the nuclear receptor corepressor RIP140 in the regulation of E2F activity is discussed below.

\subsubsection{E2F Signaling and Regulation of Cell Proliferation by Estrogens and Antiestrogens}

Approximately $70 \%$ of breast cancers are ER-positive tumors and patients bearing such tumors are treated with endocrine therapies which comprise selective ER modulators such as Tamoxifen, aromatase inhibitors which target estrogen synthesis such as Letrozole or pure ER antagonists such as Fulvestrant [30]. Although hormonal interventions have proven to be very effective in breast cancer treatment, many patients develop drug resistance which represents a major clinical problem [31]. The mechanisms by which tumors escape from endocrine therapies are not fully understood and several signaling pathways have been involved in the bypass of these treatments [30]. One mechanism by which cells overcome the inhibition of ER signaling is linked to the activation of the $\mathrm{Cyclin} / \mathrm{Cdk} / \mathrm{RB} / \mathrm{E} 2 \mathrm{~F}$. In MCF-7 breast cancer cells, antiestrogens reduce the level of Cdk2 activity and decrease the level of hyperphosphorylated RB [32,33]. Moreover, the group of $\mathrm{E}$ Knudsen demonstrated that silencing of RB expression or ectopic expression of E2F3 compromised the short-term cell-cycle inhibition by antiestrogen resulting in continued cell and tumor proliferation in the presence of Tamoxifen [34]. By reanalyzing microarray datasets, the deregulation of RB/E2F target gene expression was shown to be strongly associated with recurrence in patients treated with Tamoxifen. More recently, the perturbation of the transcriptional response to RB was confirmed in antiestrogen-resistant MCF7-derived cell models [35] and an estrogen-independent role for $\mathrm{ER} \alpha$ demonstrated in driving an E2F transcriptional program [36]. This study also reported that an E2F activation gene signature correlates with a decrease in patient response to aromatase inhibitors. Altogether, these studies support the idea that hyperactivation of the E2F signaling pathway is a key determinant of the response to hormonal therapies [37].

\section{REGULATION OF THE ER AND E2F SIGNALINGS BY RIP140}

\subsection{Introduction}

Almost 20 years ago, one of the main goals in the field of nuclear receptor (NR) biology was to identify interacting partners acting as transcriptional coregulators. RIP140
(Receptor Interacting Protein of $140 \mathrm{kDa}$ ) also known as Nuclear receptor-interacting protein 1 (NRIP1), was one of the first NR coregulator to be isolated from human cancer cells by far-western blotting using the ligand binding domain of the mouse $\mathrm{ER} \alpha$ as a radiolabeled probe [38,39]. Although RIP140 has been first described as a repressor of gene expression, it can also activate transcription depending on the target transcription factors and promoters considered (see below). The human RIP140 protein is a polypeptide of 1158 amino acids which is well conserved across species. It contains two putative nuclear localization signals and several other domains important for its biological activity as a transcription factor. Four repressive domains (RD) have been identified in the RIP140 molecule [40,41]. The RD1 acts mainly by recruiting class I and II histone deacetylases (HDACs) whereas the RD2 interacts with carboxyl-terminal-binding proteins ( $\mathrm{CtBP} 1$ and $\mathrm{CtBP} 2)$ through two conserved motifs (sequences PIDLS and PINLS) [42,43]. No downstream effectors have yet been identified for RD3 and RD4 which are located in the carboxyl-terminal region of the molecule (amino acid residues 753 - 804 and 1118 1158 , respectively). Interestingly, two lysine residues located in these domains are conjugated to SUMO proteins and play an important role in controlling the repressive activity of RIP140 [44]. Extensive biochemical studies performed in the laboratory of $\mathrm{L}$ Wei have revealed a complex network of post-translational modifications (e.g. phosphorylation, acetylation or methylation) which target the RIP140 protein and affect various parameters such as its subcellular localization, interaction with partners and transcriptional regulation. Mainly as a consequence of some of these post-translational modifications, RIP140 could be delocalized in the cytoplasm where it exerts different functions. A first example deals with the regulation of glucose uptake through the control of glucose transporter type 4 (GLUT4) trafficking which involves interaction with the 160-KDa Akt substrate, AS160 [45]. Another effect of cytoplasmic RIP140 has been demonstrated in lipid metabolism of adipocytes with a positive regulation of lipolysis through its direct interaction of RIP140 with perilipin [46]. Besides its interaction with various members of the NR superfamily, RIP140 has also been evidenced as a regulator of other transcription factors like the aryl hydrocarbon receptor (AhR) [47]. More recently, it has been shown that, in murine macrophages, RIP140 positively controls the expression of proinflammatory genes such as $I L 1 \beta$, IL6 or $T N F \alpha$ [48]. The ability of RIP140 to function as a transcriptional activator of cytokine gene transcription relies on direct protein-protein interactions with the NFאB subunit RelA and histone acetylase cAMP-responsive element binding protein (CREB)-binding protein (CBP). Using genetically manipulated mice (mainly constitutive gene knockout mice), 
several laboratories have deciphered the physiological roles of RIP140, highlighting a wide spectrum of major phenotypes dealing for instance with metabolism, reproduction, heart and mammary gland physiology or behavior $[49,50]$.

\subsection{RIP140 as a Regulator of Estrogen Signaling}

\subsubsection{Interaction of RIP140 with ER $\alpha$}

RIP140 was originally identified as a repressor of the estrogen receptor ER $\alpha$ in human breast cancer cells [39]. As transcription coactivators, RIP140 is recruited to ER $\alpha$ in the presence of agonist by means of short helical motifs which exhibit the LXXLL consensus amino acid sequence. These motifs facilitate protein-protein interactions and docking on NR ligand-binding domains in their apo conformation. The RIP140 protein contains nine LxxLL motifs thus offering a great diversity in term of NR interaction [51]. Depending on the promoter context and post-translational modifications, this conformational adaptation allows RIP140 to function as a scaffold for the assembly of chromatin remodeling complexes. Several studies have demonstrated the ligand-dependent recruitment of RIP140 on target genes in intact cells using the chromatin immunoprecipitation technique. This was for instance described on the RAR $\alpha$ promoter in the presence of E2 [52]. A recent paper reported a ChIP-Seq analysis of RIP140 target genes in MCF-7 cells treated by $17 \beta$-estradiol [53]. Surprisingly, this whole-genome binding sites analysis revealed only 2000 binding sites for RIP140 representing less than $5 \%$ of the genes targeted by ER $\alpha$ in the same conditions.

\subsubsection{Effect of RIP140 on ER $\alpha$ and ER $\beta$}

One of the hypotheses to explain the inhibitory effect of $\mathrm{ER} \beta$ on E2 regulation of gene expression and cell proliferation implies a differential recruitment of transcriptional coregulators by the two ER subtypes. Previous studies have reported $\operatorname{ER} \beta[54,55]$ or $\operatorname{ER} \alpha[56,57]$ specific interaction with different coregulators. A recent analysis of the nuclear interactomes of the two ER subtypes revealed only a small set of common proteins [58]. Interestingly, using various approaches (GST pull down, anisotropy measurements, FCCS and ChIP assays), we have recently demonstrated that RIP140 was preferentially interacting with $\mathrm{ER} \beta$ as compared with ER $\alpha$ [59]. Moreover, our results obtained after siRNA-mediated knockdown of RIP140 expression in BG1 ovarian cancer cells demonstrated the key role of RIP140 in the repressive effect exerted by activated ER $\beta$ on the regulation of EREcontrolled transcription by estrogens. This preferential interaction of RIP140 with ER $\beta$ was supported by global ChIP-Seq analysis showing that, in MCF-7 breast cancer cells, the number of RIP140-binding sites was increased by about 4-fold upon ER $\beta$ expression [53].

\subsubsection{Ternary Complex Involving ERs and RIP140}

In addition to the ERE-mediated regulation of gene expression, ERs are involved in protein-protein interaction with other transcription factors such as Sp1 or AP1 [60, 61]. In some cases, it has been reported that such complex are also regulated by RIP140. For instance, AP1mediated transcription is increased by $\mathrm{ER} \alpha$ through a direct interaction with c-Jun and the recruitment of the coactivator GRIP1/NCOA2. This estradiol-induced AP1-dependent transcription is inhibited by RIP140 in a dose-dependent manner [62]. In HepG2 cells, the inhibition of the PROS1 gene transcription by estrogen involves the interaction of ER with $\mathrm{Sp}$ proteins and the recruitment of RIP140 and a NCoR-SMRT-HDAC3 complex on the proximal region of the PROS1 promoter, as demonstrated by chromatin immunoprecipitation assays [63]. Another crosstalk involves the aryl hydrocarbon receptor (AhR) which interacts with ER $\alpha$ and inhibits E2 target genes when activated by ligands such as polycyclic aromatic or halogenated hydrocarbons. Different mechanisms have been reported involving proteasomal degradation of ER $\alpha$ [64] or squelching of common coactivators [65]. More recently, a new mechanism by which AhR regulates $\mathrm{ER} \alpha$ action in breast cancer cells has been proposed. It involves the formation of a ternary complex with RIP140 on ER $\alpha$-binding sites as demonstrated by ChIP-reChIP studies on the LRRC54 or HSPB8 gene promoters [66].

\subsection{Effects of RIP140 on the E2F Pathway}

\subsubsection{Interaction of RIP140 with E2Fs}

By means of various approaches, the interaction between RIP140 and E2F1 was clearly demonstrated [67]. Using in vitro GST pull-down assays, the respective binding sites on the two proteins were delineated. Two regions of the RIP140 molecule spanning from amino acids 119 to 199 and 916 to 1158 are involved in the interaction with the N-terminus of E2F1. Co-immunoprecipitation experiments and ChIP assays confirmed that the interaction between RIP140 and E2F1 occurs in intact cells.

\subsubsection{RIP140 Inhibits E2F Target Gene Expression}

In transiently transfected MCF-7 breast cancer cells, RIP140 ectopic expression resulted in a significant dosedependent inhibition of E2F1 activity measured on different E2F reporter promoters such as the $C C N E$ or $C D K N 2 A$ promoters. This repressive activity of RIP140 was also observed in other human cancer cell lines and on the two other activator E2Fs, i.e. E2F2 and E2F3. Moreover, the expression of several E2F target genes (CCNE, CCNB2, CDC2 and CDC6) was strongly decreased in MCF-7 breast cancer cells overexpressing a chimaeric GFP-RIP140 protein. However, the negative regulation was not observed for all E2F-target genes 
since for instance, the DHFR mRNA levels were not significantly affected. In agreement with the inhibition of E2F activity, RIP140 reduced the proportion of cells in S phase after ectopic expression in various human cell lines.

\subsubsection{Inverse Correlation between RIP140 and E2F Target Gene Expression}

To emphasize the biological significance of E2F inhibition by RIP140, the expression of RIP140 and E2F1-target genes were analyzed on a tumor microarray data set of 170 breast cancer samples [68]. A clustering analysis clearly showed that, in this cohort of human breast cancers, RIP140-deficiency is inversely correlated with the expression of several E2F1-target genes (CCNE1, MYBL2, $B I R C 5, E 2 F 1, C C N B 2$ and $C D C 6)$. Moreover, variations of RIP140 expression discriminate between molecular subtypes, low RIP140 mRNA expression being associated with basal-like tumors.

\section{REGULATION OF RIP140 EXPRESSION BY ESTROGENS AND E2FS}

\subsection{Structure and Regulation of the RIP140 Gene}

The human RIP140 gene is located in a gene-poor region of chromosome 21 q11.2 [69]. Interestingly, the RIP140 coding sequence is comprised in a single large exon with several short non-coding exons which undergo alternative splicing placing the promoter about $100 \mathrm{~kb}$ upstream of the ATG [70]. RIP140 is a widely expressed gene and in the mouse, the mRNA is detected in all the tissues with a strong expression in the testis and in the brain [71]. The RIP140 mRNA is present in a large number of cancer cell lines where it appears regulated by various nuclear receptors [72].

\subsection{RIP140 as an Estrogen Induced Gene}

We initially reported that RIP140 gene expression was regulated by $17 \beta$-estradiol (E2) in MCF-7 human breast cancer cells [38]. Several studies using global gene expression profiling also identified RIP140 as an estrogeninduced gene in breast cancer MCF-7 cells [19]. More recently, using the Rank product method, a meta-analysis of several expression studies provided a list of genes differentially expressed upon E2 stimulation [73]. By analyzing 9 time-series data sets, the authors identified between 1000 and 2000 target genes mostly related to cell signaling and proliferation which exhibit an early regulation by estrogens (i.e. 3-4 hrs post E2 treatment). The $R I P 140$ gene was well ranked in this list of early up-regulated genes. The regulation of RIP140 expression by estrogens is independent of protein synthesis [74], direct (i.e. it does not require synthesis of an intermediary protein as judged by the absence of effect of cycloheximide) and operates at the transcriptional level [70]. A consensus ERE (which binds the ER $\alpha$ in gel shift and ChIP experiments) has been mapped in the 5' proximal region of the gene $[20,70,75]$ and it has been proposed that FoxA1 sites might function as an enhancer facilitating the recruitment of ER $\alpha$ on the RIP140 promoter [76]. In MCF7 cells, the regulation was preferentially mediated by $\mathrm{ER} \alpha$ as indicated by the use of the specific agonist ligand 4,4',4"'-(4-propyl-[1H]-pyrazole-1,3,5-triyl) trisphenol (PPT). These results were confirmed using HeLa cells stably transfected with either $\mathrm{ER} \alpha$ or $\operatorname{ER} \beta$ expression vector [77] or MDA-MB 231 breast cancer cells infected with recombinant adenovirus expressing either variant of the ER. In MCF-7 cells, we showed that ER antagonist ligands such as 4-hydroxy Tamoxifen, Raloxifene or the pure antiestrogen ICI 182,780 did not increase the steady-state levels of RIP140 mRNA [70]. The regulation by estrogens was not restricted to mammary cancer cells since similar increase of RIP140 mRNA levels by estradiol was observed in human ovarian cancer cells [59]. In addition, transcriptional profilings of ER-regulated genes using stably transfected U2OS cells expressing either $\mathrm{ER} \alpha$ or $\mathrm{ER} \beta$ have also identified RIP140 as an E2-regulated gene although the relative induction by the two isoforms of ER varied according to the study [78,79].

\subsection{E2Fs Control RIP140 Transcription}

We recently published the identification and characterization of E2F binding sites in the proximal promoter region of the RIP140 gene [80]. Using gel shift experiments, we showed that E2F1 strongly interacts with oligonucleotides encompassing the putative binding sites. ChIP experiments demonstrate that the interaction of E2F1/DP1 with the proximal promoter region occurred in intact cells. Moreover, transient transfection experiments demonstrate a transcriptional regulation of the human and mouse RIP140 promoters by E2F1, E2F2 and E2F3 and promoter mutagenesis (deletion and point mutations) suggested a complex regulation of the RIP140 promoter by E2F1, involving a combination of direct and indirect recruitment through $\mathrm{Sp} 1$ similar to the regulation of SRC3 by E2F1 [11]. Interestingly, a significant increase in the levels of endogenous RIP140 mRNA was observed upon ectopic overexpression of E2F1 and DP1, thus confirming that RIP140 is a transcriptional target of E2F1 and could explain the variation in RIP140 expression observed after cell synchronization.

\subsection{Nuclear Cross-Talks Involving RIP140}

Auto-and cross-regulation between members of the nuclear receptor superfamily appear important for the coor- 
dination of hormone action in a temporal and tissue-specific manner and for the regulation of hormonal signals through positive or negative feedbacks [81]. Several indirect transcriptional cross-talks involving the regulation of RIP140 gene expression have been reported. Treatment of MCF-7 cells with 2,3,7,8-tetrachlorodi-benzo-pdioxin (TCDD), an agonist of the arylhydrocarbon receptor (AhR) induced a two-fold increase in RIP140 mRNA steady state level [70]. This TCDD-mediated increase in RIP140 expression could lead to a transrepression of ER activity and thus participate in the antiestrogenic effect of AhR $[82,83]$. RIP140 mRNA expression was also shown to be induced by all-trans retinoic acid in human embryonic carcinoma cells and in MCF-7 cells [84], suggesting that RIP140 might mediate some of the anti-estrogenic effects of retinoic acid [85]. Indeed, RIP140 knock-down using siRNA reverse the antiestrogenic effect of retinoic acid on an ERE-mediated transcriptional response. RIP140 appears to be a limiting factor in the estrogen signaling pathway since silencing its expression leads to an enhancement of the mitogenic effect of estrogens [85]. As a consequence, the nuclear receptors which positively regulate RIP140 expression (i.e. vitamin D [86], progestin [87], androgens [88] and ERRs [89]) have all the potential to inhibit estrogen-induced proliferation. It should be mentioned that this straightforward interference should be counterbalanced by the competition of the different nuclear receptors for a limiting pool of RIP140 protein. Interestingly, such interference should also exist with the other transcription factors targeted by RIP140 (E2F, $\mathrm{NFkB} \ldots$..) and further work is necessary to decipher these different levels of cross-talk.

\section{CONCLUSIONS-PERSPECTIVES}

The interactions between transcription factors and their target genes play a key role in the regulation of cellular processes. These molecular circuitries which control the expression levels of genes are dialoguing with each other and deregulation of these cross-talks is responsible for a variety of pathological events such as cancer. The transcriptional coregulator RIP140 is engaged not only in regulatory feed-back loops but also in repressive crosstalks occurring between different nuclear signaling pathways. RIP140 regulates the transactivation potential of estrogen receptors and E2Fs and is a direct transcriptional target of these transcription factors. Due to ratelimiting cellular levels, a subtle regulation of RIP140 expression (through transcriptional regulation or protein titration) may have important consequences on the other transcription networks targeted by this coregulator. This could be relevant in the case of molecular circuitries involving estrogen receptors and $\mathrm{E} 2 \mathrm{~F}$ transcription factors such as resistance to endocrine therapies. Another cell parameter which could be impacted by such cross-talks is cell metabolism. RIP140 is a main regulator of cellular metabolic circuitries and some of these regulations may involve cross-talks between E2Fs and nuclear receptors.

The present review mainly focuses on dialogue within the nucleus. However, RIP140 and ER $\alpha$ are also cytoplasmic proteins and further work will be necessary to determine whether RIP140 participates in the regulation of non-genomic action of estrogens and the nature of cross-talks in this cellular compartment. Moreover, additional studies are required to fully decipher the role of the multiple post-translational modifications of the different partners in cross-talk settings. Finally, RIP140 may be involved in the regulation of other signaling pathways which are also interconnected with estrogen receptor pathways such as the Wnt or p53 signaling which have been shown to be important for the resistance to antiestrogens $[90,91]$. Further genome wide profiling of RIP140 binding sites in breast cancer cells is obviously needed to address these issues.

\section{REFERENCES}

[1] Dahlman-Wright, K., Cavailles, V., Fuqua, S.A., Jordan, V.C., Katzenellenbogen, J.A., Korach, K.S., Maggi, A., Muramatsu, M., Parker, M.G. and Gustafsson, J.-A. (2006) International Union of Pharmacology. LXIV. Estrogen receptors. Pharmacological Reviews, 58, 773-781. http://dx.doi.org/10.1124/pr.58.4.8

[2] Manavathi, B., Dey, O., Gajulapalli, V.N.R., Bhatia, R.S., Bugide, S. and Kumar, R. (2013) Derailed estrogen signaling and breast cancer: An authentic couple. Endocrine Reviews, 34, 1-32. http://dx.doi.org/10.1210/er.2011-1057

[3] Obiorah, I. and Jordan, V.C. (2011) Progress in endocrine approaches to the treatment and prevention of breast cancer. Maturitas, 70, 315-321.

http://dx.doi.org/10.1016/j.maturitas.2011.09.006

[4] Levin, E.R. (2011) Minireview: Extranuclear steroid receptors: Roles in modulation of cell functions. Molecular Endocrinology (Baltimore, Md.), 25, 377-384. http://dx.doi.org/10.1210/me.2010-0284

[5] Le Romancer, M., Poulard, C., Cohen, P., Sentis, S., Renoir, J.-M. and Corbo, L. (2011) Cracking the estrogen receptor's posttranslational code in breast tumors. Endocrine Reviews, 32, 597-622.

http://dx.doi.org/10.1210/er.2010-0016

[6] Chen, H.-Z., Tsai, S.-Y. and Leone, G. (2009) Emerging roles of E2Fs in cancer: An exit from cell cycle control. Nature Reviews Cancer, 9, 785-797. http://dx.doi.org/10.1038/nrc2696

[7] Indovina, P., Marcelli, E., Casini, N., Rizzo, V. and Giordano, A. (2013) Emerging roles of RB family: New defense mechanisms against tumor progression. Journal of Cellular Physiology, 228, 525-535. http://dx.doi.org/10.1002/jep. 24170

[8] Du, W. and Searle, J.S. (2009) The rb pathway and cancer therapeutics. Current Drug Targets, 10, 581-589. http://dx.doi.org/10.2174/138945009788680392 
[9] Macaluso, M., Cinti, C., Russo, G., Russo, A. and Giordano, A. (2003) pRb2/p130-E2F4/5-HDAC1-SUV39H1p300 and pRb2/p130-E2F4/5-HDAC1-SUV39H1-DNMT1 multimolecular complexes mediate the transcription of estrogen receptor-alpha in breast cancer. Oncogene, 22, 3511-3517. http://dx.doi.org/10.1038/sj.onc.1206578

[10] Umemura, S., Shirane, M., Takekoshi, S., Kusakabe, T., Itoh, J., Egashira, N., Tokuda, Y., Mori, K. and Osamura, Y.R. (2009) Overexpression of E2F-5 correlates with a pathological basal phenotype and a worse clinical outcome. British Journal of Cancer, 100, 764-771. http://dx.doi.org/10.1038/sj.bjc.6604900

[11] Mussi, P., Yu, C., O’Malley, B.W. and Xu, J. (2006) Stimulation of steroid receptor coactivator-3 (SRC-3) gene overexpression by a positive regulatory loop of E2F1 and SRC-3. Molecular Endocrinology (Baltimore, Md.), 20, 3105-3119. http://dx.doi.org/10.1210/me.2005-0522

[12] Batsché, E., Desroches, J., Bilodeau, S., Gauthier, Y. and Drouin, J. (2005) Rb enhances p160/SRC coactivator-dependent activity of nuclear receptors and hormone responsiveness. The Journal of Biological Chemistry, 280, 19746-19756. http://dx.doi.org/10.1074/jbc.M413428200

[13] Macaluso, M., Montanari, M., Noto, P.B., Gregorio, V., Surmacz, E. and Giordano, A. (2006) Nuclear and cytoplasmic interaction of $\mathrm{pRb} 2 / \mathrm{p} 130$ and ER-beta in MCF-7 breast cancer cells. Annals of Oncological Office Journal of European Society for Medical Oncology ESMO, 17, vii27-vii29. http://dx.doi.org/10.1093/annonc/md1945

[14] Abbondanza, C., Medici, N., Nigro, V., Rossi, V., Gallo, L., Piluso, G., Belsito, A., Roscigno, A., Bontempo, P., Puca, A.A., Molinari, A.M., Moncharmont, B. and Puca, G.A. (2000) The retinoblastoma-interacting zinc-finger protein RIZ is a downstream effector of estrogen action. Proceedings of the National Academy of Sciences of the USA, 97, 3130-3135. http://dx.doi.org/10.1073/pnas.97.7.3130

[15] Chua, S.S., Ma, Z., Ngan, E. and Tsai, S.Y. (2004) Cdc25B as a steroid receptor coactivator. Vitamins \& Hormones, 68, 231-256. http://dx.doi.org/10.1016/S0083-6729(04)68008-3

[16] Weigel, N.L. and Moore, N.L. (2007) Cyclins, cyclin dependent kinases, and regulation of steroid receptor action. Molecular and Cellular Endocrinology, 265-266, 157161. http://dx.doi.org/10.1016/j.mce.2006.12.013

[17] Ngwenya, S. and Safe, S. (2003) Cell context-dependent differences in the induction of E2F-1 gene expression by $17 \beta$-estradiol in MCF-7 and ZR-75 cells. Endocrinology, 144, 1675-1685. http://dx.doi.org/10.1210/en.2002-0009

[18] Zhou, W., Srinivasan, S., Nawaz, Z. and Slingerland, J.M. (2013) ER $\alpha$, SKP2 and E2F-1 form a feed forward loop driving late $\mathrm{ER} \alpha$ targets and G1 cell cycle progression. Oncogene, in press. http://dx.doi.org/10.1038/onc.2013.197

[19] Stender, J.D., Frasor, J., Komm, B., Chang, K.C.N., Kraus, W.L. and Katzenellenbogen, B.S. (2007) Estrogen-regulated gene networks in human breast cancer cells: Involvement of E2F1 in the regulation of cell proliferation. Molecular Endocrinology (Baltimore, Md.), 21, 21122123. http://dx.doi.org/10.1210/me.2006-0474

[20] Bourdeau, V., Deschênes, J., Laperrière, D., Aid, M.,
White, J.H. and Mader, S. (2008) Mechanisms of primary and secondary estrogen target gene regulation in breast cancer cells. Nucleic Acids Research, 36, 76-93. http://dx.doi.org/10.1093/nar/gkm945

[21] Tu, Z., Prajapati, S., Park, K.-J., Kelly, N.J., Yamamoto, Y. and Gaynor, R.B. (2006) IKK alpha regulates estrogen-induced cell cycle progression by modulating E2F1 expression. The Journal of Biological Chemistry, 281, 6699-6706. http://dx.doi.org/10.1074/jbc.M512439200

[22] Hartman, J., Müller, P., Foster, J.S., Wimalasena, J., Gustafsson, J.-A. and Ström, A. (2004) HES-1 inhibits 17beta-estradiol and heregulin-beta1-mediated upregulation of E2F-1. Oncogene, 23, 8826-8833.

http://dx.doi.org/10.1038/sj.onc.1208139

[23] Planas-Silva, M.D. and Weinberg, R.A. (1997) Estrogendependent cyclin E-cdk2 activation through p21 redistribution. Molecular and Cellular Biology, 17, 4059-4069.

[24] Prall, O.W., Sarcevic, B., Musgrove, E.A., Watts, C.K. and Sutherland, R.L. (1997) Estrogen-induced activation of Cdk4 and Cdk2 during G1-S phase progression is accompanied by increased cyclin D1 expression and decreased cyclin-dependent kinase inhibitor association with cyclin E-Cdk2. The Journal of Biological Chemistry, 272, 10882-10894. http://dx.doi.org/10.1074/jbc.272.16.10882

[25] Foster, J.S., Henley, D.C., Ahamed, S. and Wimalasena, J. (2001) Estrogens and cell-cycle regulation in breast cancer. Trends in Endocrinology \& Metabolism TEM, 12, 320-327.

http://dx.doi.org/10.1016/S1043-2760(01)00436-2

[26] Morris, L., Allen, K.E. and La Thangue, N.B. (2000) Regulation of E2F transcription by cyclin E-Cdk2 kinase mediated through p300/CBP co-activators. Nature Cell Biology, 2, 232-239. http://dx.doi.org/10.1038/35041123

[27] Martinez-Balbas, M.A., Bauer, U.M., Nielsen, S.J., Brehm, A. and Kouzarides, T. (2000) Regulation of E2F1 activity by acetylation. EMBO Journal, 19, 662-671. http://dx.doi.org/10.1093/emboj/19.4.662

[28] Kong, H.J., Yu, H.J., Hong, S., Park, M.J., Choi, Y.H., An, W.G., Lee, J.W. and Cheong, J. (2003) Interaction and functional cooperation of the cancer-amplified transcriptional coactivator activating signal cointegrator-2 and E2F1 in cell proliferation. Molecular Cancer Research MCR, 1, 948-958.

[29] Louie, M.C., Zou, J.X., Rabinovich, A. and Chen, H.W. (2004) ACTR/AIB1 functions as an E2F1 coactivator to promote breast cancer cell proliferation and antiestrogen resistance. Molecular and Cellular Biology, 24, 51575171 . http://dx.doi.org/10.1128/MCB.24.12.5157-5171.2004

[30] Musgrove, E.A. and Sutherland, R.L. (2009) Biological determinants of endocrine resistance in breast cancer. $\mathrm{Na}$ ture Reviews Cancer, 9, 631-643.

[31] Jordan, V.C. and O'Malley, B.W. (2007) Selective estrogen-receptor modulators and antihormonal resistance in breast cancer. Journal of Clinical Oncology Office and American Society of Clinical Oncology, 25, 5815-5824. http://dx.doi.org/10.1200/JCO.2007.11.3886

[32] Wilcken, N.R., Sarcevic, B., Musgrove, E.A. and Sutherland, R.L. (1996) Differential effects of retinoids and an- 
tiestrogens on cell cycle progression and cell cycle regulatory genes in human breast cancer cells. Cell Growth \& Differentiation Journal of Molecular Biology American Association for Cancer Research, 7, 65-74.

[33] Carroll, J.S., Prall, O.W., Musgrove, E.A. and Sutherland, R.L. (2000) A pure estrogen antagonist inhibits cyclin ECdk2 activity in MCF-7 breast cancer cells and induces accumulation of p130-E2F4 complexes characteristic of quiescence. The Journal of Biological Chemistry, 275, 38221-38229. http://dx.doi.org/10.1074/jbc.M004424200

[34] Bosco, E.E., Wang, Y., Xu, H., Zilfou, J.T., Knudsen, K.E., Aronow, B.J., Lowe, S.W. and Knudsen, E.S. (2007) The retinoblastoma tumor suppressor modifies the therapeutic response of breast cancer. The Journal of Clinical Investigation, 117, 218-228. http://dx.doi.org/10.1172/JCI28803

[35] Thangavel, C., Dean, J.L., Ertel, A., Knudsen, K.E., Aldaz, C.M., Witkiewicz, A.K., Clarke, R. and Knudsen, E.S. (2011) Therapeutically activating RB: Reestablishing cell cycle control in endocrine therapy-resistant breast cancer. Endocrine-Related Cancer, 18, 333-345. http://dx.doi.org/10.1530/ERC-10-0262

[36] Miller, T.W., Balko, J.M., Fox, E.M., Ghazoui, Z., Dunbier, A., Anderson, H., Dowsett, M., Jiang, A., Smith, R.A., Maira, S.-M., Manning, H.C., González-Angulo, A.M., Mills, G.B., Higham, C., Chanthaphaychith, S., Kuba, M.G., Miller, W.R., Shyr, Y. and Arteaga, C.L. (2011) ER $\alpha$-dependent E2F transcription can mediate resistance to estrogen deprivation in human breast cancer. Cancer Discovery, 1, 338-351. http://dx.doi.org/10.1158/2159-8290.CD-11-0101

[37] Bosco, E.E. and Knudsen, E.S. (2007) RB in breast cancer: The crossroads of tumorigenesis and treatment. Cell Cycle, 6, 667-671. http://dx.doi.org/10.4161/cc.6.6.3988

[38] Cavailles, V., Dauvois, S., Danielian, P.S. and Parker, M.G. (1994) Interaction of proteins with transcriptionally active estrogen receptors. Proceedings of the National Academy of Sciences of the United States of America, 91, 10009-10013. http://dx.doi.org/10.1073/pnas.91.21.10009

[39] Cavailles, V., Dauvois, S., L’Horset, F., Lopez, G., Hoare, S., Kushner, P.J. and Parker, M.G. (1995) Nuclear factor RIP140 modulates transcriptional activation by the estrogen receptor. EMBO Journal, 14, 3741-3751.

[40] Castet, A., Boulahtouf, A., Versini, G., Bonnet, S., Augereau, P., Vignon, F., Khochbin, S., Jalaguier, S. and Cavailles, V. (2004) Multiple domains of the receptorinteracting protein 140 contribute to transcription inhibittion. Nucleic Acids Research, 32, 1957-1966. http://dx.doi.org/10.1093/nar/gkh524

[41] Christian, M., Tullet, J.M. and Parker, M.G. (2004) Characterization of four autonomous repression domains in the corepressor receptor interacting protein 140. The Journal of Biological Chemistry, 279, 15645-15651. http://dx.doi.org/10.1074/jbc.M313906200

[42] Wei, L.N., Hu, X., Chandra, D., Seto, E. and Farooqui, M. (2000) Receptor-interacting protein 140 directly recruits histone deacetylases for gene silencing. The Journal of Biological Chemistry, 275, 40782-40787.
http://dx.doi.org/10.1074/jbc.M004821200

[43] Vo, N., Fjeld, C. and Goodman, R.H. (2001) Acetylation of nuclear hormone receptor-interacting protein RIP140 regulates binding of the transcriptional corepressor CtBP. Molecular and Cellular Biology, 21, 6181-6188. http://dx.doi.org/10.1128/MCB.21.18.6181-6188.2001

[44] Rytinki, M.M. and Palvimo, J.J. (2008) SUMOylation modulates the transcription repressor function of RIP140. The Journal of Biological Chemistry, 283, 11586-11595. http://dx.doi.org/10.1074/jbc.M709359200

[45] Ho, P.-C., Lin, Y.-W., Tsui, Y.-C., Gupta, P. and Wei, L.-N. (2009) A negative regulatory pathway of GLUT4 trafficking in adipocyte: New function of RIP140 in the cytoplasm via AS160. Cell Metabolism, 10, 516-523. http://dx.doi.org/10.1016/j.cmet.2009.09.012

[46] Ho, P.-C., Chuang, Y.-S., Hung, C.-H. and Wei, L.-N. (2011) Cytoplasmic receptor-interacting protein 140 (RIP140) interacts with perilipin to regulate lipolysis. Cellular Signalling, 23, 1396-1403. http://dx.doi.org/10.1016/j.cellsig.2011.03.023

[47] Kumar, M.B., Tarpey, R.W. and Perdew, G.H. (1999) Differential recruitment of coactivator RIP140 by Ah and estrogen receptors. Absence of a role for LXXLL motifs. The Journal of Biological Chemistry, 274, 22155-22164. http://dx.doi.org/10.1074/jbc.274.32.22155

[48] Zschiedrich, I., Hardeland, U., Krones-Herzig, A., Berriel, D.M., Vegiopoulos, A., Müggenburg, J., Sombroek, D., Hofmann, T.G., Zawatzky, R., Yu, X., Gretz, N., Christian, M., White, R., Parker, M.G. and Herzig, S. (2008) Coactivator function of RIP140 for NFkappaB/RelA-dependent cytokine gene expression. Blood, 112, 264-276. http://dx.doi.org/10.1182/blood-2007-11-121699

[49] Nautiyal, J., Christian, M. and Parker, M.G. (2013) Distinct functions for RIP140 in development, inflammation, and metabolism. Trends in Endocrinology \& Metabolism, in press. http://dx.doi.org/10.1016/j.tem.2013.05.001

[50] Ho, P.-C. and Wei, L.-N. (2012) Biological activities of receptor-interacting protein 140 in adipocytes and metabolic diseases. Current Diabetes Reviews, 8, 452-457. http://dx.doi.org/10.2174/157339912803529922

[51] Heery, D.M., Kalkhoven, E., Hoare, S. and Parker, M.G. (1997) A signature motif in transcriptional co-activators mediates binding to nuclear receptors. Nature, 387, 733736.

[52] Laganière, J., Deblois, G. and Giguère, V. (2005) Functional genomics identifies a mechanism for estrogen activation of the retinoic acid receptor alphal gene in breast cancer cells. Molecular Endocrinology, 19, 1584-1592. http://dx.doi.org/10.1210/me.2005-0040

[53] Madak-Erdogan, Z., Charn, T.-H., Jiang, Y., Liu, E.T., Katzenellenbogen, J.A. and Katzenellenbogen, B.S. (2013) Integrative genomics of gene and metabolic regulation by estrogen receptors $\alpha$ and $\beta$, and their coregulators. Molecular Systems Biology, 9, Article ID: 676. http://dx.doi.org/10.1038/msb.2013.28

[54] Warnmark, A., Almlof, T., Leers, J., Gustafsson, J.A. and Treuter, E. (2001) Differential recruitment of the mammalian mediator subunit TRAP220 by estrogen receptors ERalpha and ERbeta. The Journal of Biological Chemis- 
try, 276, 23397-23404.

http://dx.doi.org/10.1074/jbc.M011651200

[55] Kouzu-Fujita, M., Mezaki, Y., Sawatsubashi, S., Matsumoto, T., Yamaoka, I., Yano, T., Taketani, Y., Kitagawa, H. and Kato, S. (2009) Coactivation of estrogen receptor beta by gonadotropin-induced cofactor GIOT-4. Molecular and Cellular Biology, 29, 83-92. http://dx.doi.org/10.1128/MCB.00884-08

[56] Garcia-Pedrero, J.M., Del Rio, B., Martinez-Campa, C., Muramatsu, M., Lazo, P.S. and Ramos, S. (2002) Calmodulin is a selective modulator of estrogen receptors. Molecular Endocrinology, 16, 947-960. http://dx.doi.org/10.1210/me.16.5.947

[57] García-Pedrero, J.M., Kiskinis, E., Parker, M.G. and Belandia, B. (2006) The SWI/SNF chromatin remodeling subunit BAF57 is a critical regulator of estrogen receptor function in breast cancer cells. The Journal of Biological Chemistry, 281, 22656-22664. http://dx.doi.org/10.1074/jbc.M602561200

[58] Nassa, G., Tarallo, R., Guzzi, P.H., Ferraro, L., Cirillo, F., Ravo, M., Nola, E., Baumann, M., Nyman, T.A., Cannataro, M., Ambrosino, C. and Weisz, A. (2011) Comparative analysis of nuclear estrogen receptor alpha and beta interactomes in breast cancer cells. Molecular BioSystems, 7, 667-676. http://dx.doi.org/10.1039/c0mb00145g

[59] Docquier, A., Garcia, A., Savatier, J., Boulahtouf, A., Bonnet, S., Bellet, V., Busson, M., Jalaguier, S., Margeat, E., Royer, C., Balaguer, P. and Cavailles, V. (2013) Negative regulation of estrogen signaling by ERbeta and RIP140 in ovarian cancer cells. Molecular Endocrinology, 27, 1429-1441.

[60] Porter, W., Saville, B., Hoivik, D. and Safe, S. (1997) Functional synergy between the transcription factor $\mathrm{Sp} 1$ and the estrogen receptor. Molecular Endocrinology, 11, 1569-1580. http://dx.doi.org/10.1210/me.11.11.1569

[61] Safe, S. (2001) Transcriptional activation of genes by 17 beta-estradiol through estrogen receptor-Sp1 interactions. Vitamins \& Hormones, 62, 231-252.

[62] Teyssier, C., Belguise, K., Galtier, F., Cavailles, V. and Chalbos, D. (2003) Receptor-interacting protein 140 binds c-jun and inhibits estradiol-induced activator protein-1 activity by reversing glucocorticoid receptor-interacting protein 1 effect. Molecular Endocrinology, 17, 287-299. http://dx.doi.org/10.1210/me.2002-0324

[63] Suzuki, A., Sanda, N., Miyawaki, Y., Fujimori, Y., Yamada, T., Takagi, A., Murate, T., Saito, H. and Kojima, T. (2010) Down-regulation of PROS1 gene expression by 17beta-estradiol via estrogen receptor alpha (ERalpha)$\mathrm{Sp} 1$ interaction recruiting receptor-interacting protein 140 and the corepressor-HDAC3 complex. The Journal of Biological Chemistry, 285, 13444-13453. http://dx.doi.org/10.1074/jbc.M109.062430

[64] Ohtake, F., Fujii-Kuriyama, Y. and Kato, S. (2009) AhR acts as an E3 ubiquitin ligase to modulate steroid receptor functions. Biochemical Pharmacology, 77, 474-484. http://dx.doi.org/10.1016/j.bcp.2008.08.034

[65] Reen, R.K., Cadwallader, A. and Perdew, G.H. (2002) The subdomains of the transactivation domain of the aryl hydrocarbon receptor (AhR) inhibit $\mathrm{AhR}$ and estrogen receptor transcriptional activity. Archives of Biochemistry and Biophysics, 408, 93-102.

http://dx.doi.org/10.1016/S0003-9861(02)00518-0

[66] Madak-Erdogan, Z. and Katzenellenbogen, B.S. (2012) Aryl hydrocarbon receptor modulation of estrogen recaptor $\alpha$-mediated gene regulation by a multimeric chromatin complex involving the two receptors and the coregulator RIP140. Toxicological Sciences, 125, 401-411. http://dx.doi.org/10.1093/toxsci/kfr300

[67] Docquier, A., Harmand, P.-O., Fritsch, S., Chanrion, M., Darbon, J.-M. and Cavaillès, V. (2010) The transcriptional coregulator RIP140 represses E2F1 activity and discriminates breast cancer subtypes. Clinical Cancer Research, 16, 2959-2970. http://dx.doi.org/10.1158/1078-0432.CCR-09-3153

[68] Hu, Z., Fan, C., Oh, D.S., Marron, J.S., He, X., Qaqish, B.F., Livasy, C., Carey, L.A., Reynolds, E., Dressler, L., Nobel, A., Parker, J., Ewend, M.G., Sawyer, L.R., Wu, J., Liu, Y., Nanda, R., Tretiakova, M., Ruiz Orrico, A., Dreher, D., Palazzo, J.P., Perreard, L., Nelson, E., Mone, M., Hansen, H., Mullins, M., Quackenbush, J.F., Ellis, M.J., Olopade, O.I., Bernard, P.S. and Perou, C.M. (2006) The molecular portraits of breast tumors are conserved across microarray platforms. BMC Genomics, 7, 96. http://dx.doi.org/10.1186/1471-2164-7-96

[69] Katsanis, N., Ives, J.H., Groet, J., Nizetic, D. and Fisher, E.M. (1998) Localisation of receptor interacting protein 140 (RIP140) within $100 \mathrm{~kb}$ of D21S13 on 21q11, a gene-poor region of the human genome. Human Genetics, 102, 221-223. http://dx.doi.org/10.1007/s004390050682

[70] Augereau, P., Badia, E., Fuentes, M., Rabenoelina, F., Corniou, M., Derocq, D., Balaguer, P. and Cavailles, V. (2006) Transcriptional regulation of the human NRIP1/ RIP140 gene by estrogen is modulated by dioxin signalling. Molecular Pharmacology, 69, 1338-1346.

http://dx.doi.org/10.1124/mol.105.017376

[71] Lee, C.H., Chinpaisal, C. and Wei, L.N. (1998) Cloning and characterization of mouse RIP140, a corepressor for nuclear orphan receptor TR2. Molecular and Cellular Biology, 18, 6745-6755.

[72] Christian, M., White, R. and Parker, M.G. (2006) Metabolic regulation by the nuclear receptor corepressor RIP140. Trends in Endocrinology \& Metabolism, 17, 243-250. http://dx.doi.org/10.1016/j.tem.2006.06.008

[73] Jagannathan, V. and Robinson-Rechavi, M. (2011) Metaanalysis of estrogen response in MCF-7 distinguishes early target genes involved in signaling and cell proliferation from later target genes involved in cell cycle and DNA repair. BMC Systems Biology, 5, 138. http://dx.doi.org/10.1186/1752-0509-5-138

[74] Thenot, S., Charpin, M., Bonnet, S. and Cavailles, V. (1999) Estrogen receptor cofactors expression in breast and endometrial human cancer cells. Molecular and Cellular Endocrinology, 156, 85-93. http://dx.doi.org/10.1016/S0303-7207(99)00139-2

[75] Lin, C.-Y., Ström, A., Vega, V.B., Kong, S.L., Yeo, A.L., Thomsen, J.S., Chan, W.C., Doray, B., Bangarusamy, D.K., Ramasamy, A., Vergara, L.A., Tang, S., Chong, A., Bajic, V.B., Miller, L.D., Gustafsson, J.-A. and Liu, E.T. 
(2004) Discovery of estrogen receptor alpha target genes and response elements in breast tumor cells. Genome Biology, 5, R66. http://dx.doi.org/10.1186/gb-2004-5-9-r66

[76] Carroll, J.S., Liu, X.S., Brodsky, A.S., Li, W., Meyer, C.A., Szary, A.J., Eeckhoute, J., Shao, W., Hestermann, E.V., Geistlinger, T.R., Fox, E.A., Silver, P.A. and Brown, M. (2005) Chromosome-wide mapping of estrogen receptor binding reveals long-range regulation requiring the forkhead protein FoxA1. Cell, 122, 33-43. http://dx.doi.org/10.1016/j.cell.2005.05.008

[77] Escande, A., Pillon, A., Servant, N., Cravedi, J.-P., Larrea, F., Muhn, P., Nicolas, J.-C., Cavaillès, V. and Balaguer, P. (2006) Evaluation of ligand selectivity using reporter cell lines stably expressing estrogen receptor alpha or beta. Biochemical Pharmacology, 71, 1459-1469. http://dx.doi.org/10.1016/j.bcp.2006.02.002

[78] Monroe, D.G., Getz, B.J., Johnsen, S.A., Riggs, B.L., Khosla, S. and Spelsberg, T.C. (2003) Estrogen receptor isoform-specific regulation of endogenous gene expression in human osteoblastic cell lines expressing either ERalpha or ERbeta. Journal of Cellular Biochemistry, 90, 315-326. http://dx.doi.org/10.1002/jcb.10633

[79] Stossi, F., Barnett, D.H., Frasor, J., Komm, B., Lyttle, C.R. and Katzenellenbogen, B.S. (2004) Transcriptional profiling of estrogen-regulated gene expression via estrogen receptor (ER) alpha or ERbeta in human osteosarcoma cells: Distinct and common target genes for these receptors. Endocrinology, 145, 3473-3486. http://dx.doi.org/10.1210/en.2003-1682

[80] Docquier, A., Augereau, P., Lapierre, M., Harmand, P.-O., Badia, E., Annicotte, J.-S., Fajas, L. and Cavaillès, V. (2012) The RIP140 gene is a transcriptional target of E2F1. PloS One, 7, e35839. http://dx.doi.org/10.1371/journal.pone.0035839

[81] Bagamasbad, P. and Denver, R.J. (2011) Mechanisms and significance of nuclear receptor auto- and cross-regulation. General and Comparative Endocrinology, 170, 3-17. http://dx.doi.org/10.1016/j.ygcen.2010.03.013

[82] Safe, S., Wang, F., Porter, W., Duan, R. and McDougal, A. (1998) Ah receptor agonists as endocrine disruptors: Antiestrogenic activity and mechanisms. Toxicology Letters, 102-103, 343-347. http://dx.doi.org/10.1016/S0378-4274(98)00331-2

[83] Swedenborg, E. and Pongratz, I. (2010) AhR and ARNT modulate ER signaling. Toxicology, 268, 132-138. http://dx.doi.org/10.1016/j.tox.2009.09.007

[84] Kerley, J.S., Olsen, S.L., Freemantle, S.J. and Spinella, M.J. (2001) Transcriptional activation of the nuclear receptor corepressor RIP140 by retinoic acid: A potential negative-feedback regulatory mechanism. Biochemical and Biophysical Research Communications, 285, 969975. http://dx.doi.org/10.1006/bbrc.2001.5274

[85] White, K.A., Yore, M.M., Deng, D. and Spinella, M.J. (2005) Limiting effects of RIP140 in estrogen signaling: potential mediation of anti-estrogenic effects of retinoic acid. The Journal of Biological Chemistry, 280, 78297835. http://dx.doi.org/10.1074/jbc.M412707200

[86] Lin, R. (2002) Expression profiling in squamous carcinoma cells reveals pleiotropic effects of vitamin D3 ana$\log$ EB1089 signaling on cell proliferation, differentiation, and immune system regulation. Molecular Endocrinology, 16, 1243-1256. http://dx.doi.org/10.1210/me.16.6.1243

[87] Graham, J.D., Yager, M.L., Hill, H.D., Byth, K., O’Neill, G.M. and Clarke, C.L. (2005) Altered progesterone receptor isoform expression remodels progestin responsiveness of breast cancer cells. Molecular Endocrinology, 19, 2713-2735. http://dx.doi.org/10.1210/me.2005-0126

[88] Carascossa, S., Gobinet, J., Georget, V., Lucas, A., Badia, E., Castet, A., White, R., Nicolas, J.-C., Cavaillès, V. and Jalaguier, S. (2006) Receptor-interacting protein 140 is a repressor of the androgen receptor activity. Molecular Endocrinology, 20, 1506-1518. http://dx.doi.org/10.1210/me.2005-0286

[89] Nichol, D., Christian, M., Steel, J.H., White, R. and Parker, M.G. (2006) RIP140 expression is stimulated by estrogen-related receptor alpha during adipogenesis. The Journal of Biological Chemistry, 281, 32140-32147. http://dx.doi.org/10.1074/jbc.M604803200

[90] Loh, Y.N., Hedditch, E.L., Baker, L.A., Jary, E., Ward, R.L. and Ford, C.E. (2013) The Wnt signalling pathway is upregulated in an in vitro model of acquired tamoxifen resistant breast cancer. BMC Cancer, 13, 174. http://dx.doi.org/10.1186/1471-2407-13-174

[91] Berger, C., Qian, Y. and Chen, X. (2013) The p53-estrogen receptor loop in cancer. Current Molecular Medicine, in press. 